Meta-Analysis

\title{
The association between MAD2 and prognosis in cancer: systematic review and meta-analyses
}

\author{
Tara Byrne ${ }^{1}$, Helen G. Coleman ${ }^{2}$, Janine A. Cooper ${ }^{1}$, W. Glenn McCluggage ${ }^{3}$, \\ Amanda McCann ${ }^{4,5}$ and Fiona Furlong ${ }^{1}$ \\ ${ }^{1}$ School of Pharmacy, Queen's University Belfast, Belfast, Northern Ireland, UK \\ ${ }^{2}$ Centre for Public Health, Queen's University Belfast, Belfast, Northern Ireland, UK \\ ${ }^{3}$ Department of Pathology, Belfast Health and Social Care Trust, Belfast, Northern Ireland, UK \\ ${ }^{4}$ UCD School of Medicine, College of Health and Agricultural Science, University College Dublin, Dublin, Ireland, UK \\ ${ }^{5}$ UCD Conway Institute of Biomolecular and Biomedical Research, University College Dublin, Dublin, Ireland, UK \\ Correspondence to: Fiona Furlong, email: f.furlong@qub.ac.uk
}

Keywords: MAD2, cancer, prognosis and systematic review

Received: January 10, 2017 Accepted: May 03, $2017 \quad$ Published: June 08, 2017

Copyright: Byrne et al. This is an open-access article distributed under the terms of the Creative Commons Attribution License 3.0 (CC BY 3.0), which permits unrestricted use, distribution, and reproduction in any medium, provided the original author and source are credited.

\section{ABSTRACT}

This systematic review and meta-analyses investigates the expression of the cell checkpoint regulator, mitotic arrest deficiency protein 2 (MAD2) in cancerous tissue and examines whether an association exists between MAD2 levels and cancer survival and recurrence. Studies investigating MAD2 expression in cancer tissue utilising immunohistochemistry (IHC) were identified by systematic literature searches of Medline, Embase and Web of Science databases by October 2015. Random effects meta-analyses were performed to generate pooled hazard ratios (HRs) with $\mathbf{9 5 \%}$ confidence intervals (CIs) of overall and progression-free survival according to MAD2 expression. Forty-three studies were included in the overall review. In 33 studies investigating MAD2 expression by IHC in cancer tissue, a wide range of expression positivity (11-100\%) was reported. Higher MAD2 expression was not associated with an increased risk of all-cause mortality in a range of cancers (pooled HR 1.35, 95\% CI 0.97-1.87; $P=0.077, n=15$ ). However, when ovarian cancer studies were removed, a significant pooled HR of $\mathbf{1 . 5 9}$ for risk of all-cause mortality in other cancer patients with higher expressing MAD2 tumours was evident $(95 \% \mathrm{CI}, 1.17-2.17 ; P=0.003$, $n=12$ ). In contrast, higher MAD2 expression was associated with significant decreased risk of all-cause mortality in ovarian cancer patients (pooled HR $=0.50,95 \% \mathrm{CI}$, $0.25-0.97 ; P=0.04, n=3$ ). In conclusion, with the exception of ovarian cancer, increased MAD2 expression is associated with increased risk of all-cause mortality and recurrence in cancer. For ovarian cancer, reduced levels of MAD2 are associated with poorer outcome. Further studies are critical to assess the clinical utility of a MAD2 IHC biomarker.

\section{INTRODUCTION}

The mitotic arrest deficiency protein 2 (MAD2) is an essential spindle assembly checkpoint (SAC) monitoring accurate chromosomal alignment at the metaphase plate before mitosis [1]. Much evidence implicates the overexpression of MAD2 as a driver of chromosomal instability in many cancer types [2-5]. Tumour formation resulting from loss of one of the MAD2 alleles suggests haploinsufficiency at this locus which is common to other SAC proteins [6]. MAD2 also functions beyond the SAC where it is known to interact with a number of checkpointunrelated proteins such as insulin receptor, estrogen receptor $\beta$ and tumour necrosis factor $\alpha$ convertase [7-9]. Moreover, MAD2 influences cell proliferation, tumour metastasis and tumour recurrence [5].

MAD2 expression is regulated by a diverse range of cancer-associated proteins including the tumour 
suppressor protein p53, breast cancer 1 (BRCA1), the c-MYC oncogene, the checkpoint with forkhead and ring finger domains, E3 ubiquitin protein ligase (CHFR), E2 factor (E2F) and numerous microRNAs [10-16] . Moreover, MAD2 is a ubiquitously expressed protein, expressed by most tissues of the body, found localised in the nuclear, perinuclear and cytoplasmic compartments [17-19]. It is reliably measured by real-time PCR, western blots or immunohistochemistry (IHC) methods [19, 20]. The majority of studies predominantly evaluate MAD2 expression by IHC.

The association between MAD2 IHC expression and survival has been examined in a diverse range of carcinomas including colorectal, bladder, testicular, breast and ovarian, where both overexpression and low levels of MAD2 expression have been associated with survival, depending on the tumour type [20, 21]. However, inconsistencies in terms of study design, staining site analysed, expression cut-offs and study quality have precluded the interpretations of these study results, and the evaluation of MAD2 as a potential prognostic biomarker of patient survival. Therefore, there is an unmet need to systematically review published data relating to the extent of MAD2 expression in various tissues and the relationship between MAD2 expression evaluated through IHC and cancer prognosis.

The primary aim of this novel review and metaanalyses was to systematically identify research papers that analysed the association between MAD2 IHC staining and cancer patient survival and/or recurrence, and from these studies elucidate whether there is an association between MAD2 expression and cancer patient prognosis by conducting a meta-analysis.

\section{RESULTS}

The literature search identified 881 citations for review (Medline $n=460$, Embase minus Medline $n=22$ and Web of Science $n=399$ ). As shown in Figure 1, after exclusion of publications following screening for title and abstract by reviewers, 81 papers remained and after removal of duplicates, 43 studies were fully screened and included in the review.

\section{MAD2 expression in cancerous tissue}

A total of 33 studies provided expression analysis of MAD2 where expression of positivity ranged from 11.1 to $100 \%$ in cancerous tissue. Difficulties arose in the comparison of studies due to the fact that the majority of cancer types only have one study. In cancer types where more than one study has been undertaken, comparisons between studies were extremely complicated. This was as a result of the different expression methods utilised and the expression reported as different measures of central tendency (Supplementary Table 1).

\section{Association with overall survival}

As shown in Table 1, studies included in this metaanalysis were published between 2008 and 2015, with nine studies originating from East Asia, three studies from Europe, one study from Brazil and one study from the USA. Cancer sample cohorts ranged from 27 to 400 . The mean follow-up times, ranged from 3 to 3.29 years with median follow-up times ranging from 1.6 to 5.04 year. MAD2 IHC was mostly evaluated on tissue microarrays (TMAs), one study used both TMAs and full face sections, while six studies did not report the sample type assessed. Monoclonal antibodies were reported in eight studies, three studies reported the use of polyclonal antibodies and three studies did not report the type of antibody used. The cellular location investigated for MAD2 staining was nuclear in six studies, cytoplasmic for two studies, both nuclear and cytoplasmic in five studies and unreported in one study (Table 1). In the IHC staining analysis of MAD2 expression, four studies reported the involvement of a pathologist in the scoring of the IHC slides while 10 studies did not state if a pathologist assisted in the scoring. Two assessors determined MAD2 IHC staining in six studies, a single pathologist assessed MAD2 IHC scoring in one study and the remaining seven studies did not state the number of assessors.

Sufficient data was provided by 14 studies, which contained 2318 patient samples to be included in the meta-analysis, to assess the association between MAD2 expression and overall survival (Table 2). As shown in Figure 2, higher MAD2 expression was associated with a non-significant increased risk of all-cause mortality in a range of cancers (pooled HR 1.35, 95\% CI 0.97-1.87; $P=0.08)$. This investigation had an $I^{2}$ value of $72 \%(P<0.001)$, highlighting the substantial heterogeneity between studies, which was not markedly reduced in sensitivity analyses excluding individual studies (Figure 2).

Interestingly, when all ovarian cancer studies are removed, as shown in Figure 2, a significant pooled HR of 1.59 for risk of all-cause mortality in patients with high expressing MAD2 tumours was evident compared to those with low expressing MAD2 tumours (95\% CI, 1.172.17; $P=0.003)$, but still incurred high heterogeneity $\left(\mathrm{I}^{2}=65 \%, P=0.001\right)$. When only ovarian studies were investigated as a separate entity, higher MAD2 expression was associated with a significantly decreased risk of allcause mortality compared to those with low expressing MAD2 tumours (pooled HR 0.50, 95\% CI, 0.25-0.97; $P=0.04)$. This meta-analysis had an $\mathrm{I}^{2}$ value of $27 \%$ $(P=0.25)$ indicating that the results of the studies are reliably consistent with mild heterogeneity (Figure 2). There was no evidence of publication bias in the funnel plot assessing overall survival for studies $(P=0.82$, Supplementary Figure 1). However from undertaking the meta-analysis it is evident that the different ovarian cancer subtypes may respond differently to MAD2 expression 
Table 1: Characteristics of studies assessing the expression of MAD2 immunohistochemistry in cancer

\begin{tabular}{|c|c|c|c|c|c|c|c|c|c|c|}
\hline Author & Year & Cancer site(s) & $\begin{array}{l}\text { Samples } \\
\text { assessed }\end{array}$ & $\begin{array}{c}\text { Age range, } \\
\text { years (mean or } \\
\text { median) }\end{array}$ & Sex & $\begin{array}{c}\text { Number } \\
\text { of normal } \\
\text { tissue } \\
\text { samples }\end{array}$ & $\begin{array}{l}\text { Number of } \\
\text { cancer } \\
\text { samples }\end{array}$ & Site of staining & $\begin{array}{c}\text { Expression } \\
\text { analysis }\end{array}$ & $\begin{array}{c}\text { Survival } \\
\text { analysis }\end{array}$ \\
\hline Agosten & 2007 & Breast & TMA & NR & Females & NR & 85 & $\begin{array}{l}\text { Perinuclear/ } \\
\text { cytoplasmic }\end{array}$ & $\checkmark$ & $\mathrm{X}$ \\
\hline Burum-Auensen & 2008 & Colorectal & TMA & $35-88(68)$ & $\begin{array}{l}\text { Males \& } \\
\text { females }\end{array}$ & 17 & 55 & Nuclear & $\checkmark$ & $\checkmark$ \\
\hline Burum-Auensen & 2007 & $\begin{array}{l}\text { Colorectal } \\
\text { (UC-related) }\end{array}$ & TMA & NR & NR & 10 & 8 & $\begin{array}{l}\text { Nuclear/ } \\
\text { additional staining } \\
\text { was cytoplasmic }\end{array}$ & $\checkmark$ & $\mathrm{X}$ \\
\hline Burum-Auensen & 2010 & Testicular & TMA & NR & Males & 21 & 336 & $\begin{array}{l}\text { Nuclear with } \\
\text { weak staining of } \\
\text { cytoplasm }\end{array}$ & $\checkmark$ & $\mathrm{X}$ \\
\hline Choi & 2013 & Bladder & TMA & 23-97 (68) & $\begin{array}{l}\text { Males \& } \\
\text { females }\end{array}$ & NR & 339 & $\begin{array}{l}\text { Nuclear \& } \\
\text { cytoplasmic }\end{array}$ & $\checkmark$ & $\checkmark$ \\
\hline $\mathrm{Du}$ & 2011 & Breast & NR & $33-83(54)$ & Females & NR & 117 & $\begin{array}{l}\text { Nuclear/ } \\
\text { sometimes } \\
\text { cytoplasmic }\end{array}$ & $\checkmark$ & $\mathrm{X}$ \\
\hline Fung & 2007 & Testicular & NR & $24-67(37.7)$ & Males & 12 & 23 & $\begin{array}{l}\text { Nuclear \& } \\
\text { cytoplasmic }\end{array}$ & $\checkmark$ & $\mathrm{X}$ \\
\hline Furlong & 2012 & Ovarian & $\begin{array}{l}\text { TMA and full } \\
\text { face }\end{array}$ & NR & Females & NR & 82 & Nuclear & $\checkmark$ & $\checkmark$ \\
\hline Genga & 2015 & $\begin{array}{l}\text { Myelodysplastic } \\
\text { syndrome }\end{array}$ & NR & $18-91(59.5)$ & $\begin{array}{l}\text { Males \& } \\
\text { females }\end{array}$ & 10 & 40 & Cytoplasmic & $\checkmark$ & $\checkmark$ \\
\hline Gladhaug & 2010 & Pancreatic & TMA & NR & $\begin{array}{l}\text { Males \& } \\
\text { females }\end{array}$ & NR & 218 & Nuclear & $\checkmark$ & $\checkmark$ \\
\hline Hannisdal & 2010 & Tonsillar & TMA & $\begin{array}{l}43 \text { aged }<60 \\
57 \text { aged } \geq 60\end{array}$ & $\begin{array}{l}\text { Males \& } \\
\text { females }\end{array}$ & NR & 105 & $\begin{array}{l}\text { Nuclear \& } \\
\text { cytoplasmic }\end{array}$ & $\checkmark$ & $\checkmark$ \\
\hline Hisaoka & 2008 & Sarcoma & NR & NR & NR & 50 & 50 & Nuclear & $\checkmark$ & $\mathrm{X}$ \\
\hline Kato & 2012 & Lung & TMA & $\begin{array}{l}123 \text { aged }<60 \\
239 \text { aged } \geq 60\end{array}$ & $\begin{array}{l}\text { Males \& } \\
\text { females }\end{array}$ & NR & 362 & NR & $\checkmark$ & $\mathrm{X}$ \\
\hline Kato & 2011 & Lung & TMA & $26-87(63.5)$ & $\begin{array}{l}\text { Males \& } \\
\text { females }\end{array}$ & NR & 358 & Nucleoplasmic & $\checkmark$ & $\checkmark$ \\
\hline Kim & 2014 & Uterine cervical & TMA & $22-82(44.1)$ & Females & 100 & 232 & $\begin{array}{l}\text { Nuclear \& } \\
\text { cytoplasmic }\end{array}$ & $\checkmark$ & $\checkmark$ \\
\hline Ko & 2010 & Salivary duct & NR & $42-82(58.5)$ & $\begin{array}{l}\text { Males \& } \\
\text { females }\end{array}$ & NR & 27 & Cytoplasmic & $\checkmark$ & $\checkmark$ \\
\hline $\mathrm{Li}$ & 2013 & Endometrial & NR & $35-85(51)$ & Females & $\begin{array}{l}30 \text { normal, } \\
30 \\
\text { hyperplasia }\end{array}$ & 63 & $\begin{array}{l}\text { Nuclear \& } \\
\text { cytoplasmic }\end{array}$ & $\checkmark$ & $\checkmark$ \\
\hline $\mathrm{Li}$ & 2003 & Colorectal & NR & $28-81(54.8)$ & $\begin{array}{l}\text { Males \& } \\
\text { females }\end{array}$ & 38 & 38 & $\begin{array}{l}\text { Brown-yellow } \\
\text { staining mainly in } \\
\text { cell plasma }\end{array}$ & $\checkmark$ & $\mathrm{X}$ \\
\hline $\mathrm{Li}$ & 2004 & Colorectal & NR & $25-79(52.5)$ & $\begin{array}{l}\text { Males \& } \\
\text { females }\end{array}$ & 40 & 40 & $\begin{array}{l}\text { Brown-yellow } \\
\text { staining mainly in } \\
\text { cell plasma }\end{array}$ & $\checkmark$ & $\checkmark$ \\
\hline Liao & 2013 & Cervical & NR & $23-65(43.5)$ & Females & 10 & 90 & $\begin{array}{l}\text { Nuclear \& } \\
\text { cytoplasmic }\end{array}$ & $\checkmark$ & $\mathrm{X}$ \\
\hline McGrogan & 2014 & Ovarian & TMA & $32-77(52)$ & Females & NA & 72 & Nuclear & $\checkmark$ & $\checkmark$ \\
\hline Morishta & 2012 & Uterine cervical & NR & $22-69$ & Females & NA & 53 & Nuclear & $\checkmark$ & $\mathrm{X}$ \\
\hline Nakano & 2012 & Ovarian serous & NR & $26-82$ & Females & NA & 41 & Nuclear & $\checkmark$ & $\checkmark$ \\
\hline Nakano & 2012 & $\begin{array}{l}\text { Ovarian } \\
\text { mucinous }\end{array}$ & NR & $13-88$ & Females & 30 & 98 & Nuclear & $\checkmark$ & $\checkmark$ \\
\hline Park & 2013 & Ovarian & NR & $\begin{array}{l}59 \text { aged }<60 \\
26 \text { aged } \geq 60\end{array}$ & Females & NA & 85 & $\begin{array}{l}\text { Nuclear } 7 \\
\text { cytoplasmic }\end{array}$ & $\checkmark$ & $\checkmark$ \\
\hline Rizzardi & 2014 & Oral SCC & NR & $44-86(61)$ & $\begin{array}{l}\text { Males \& } \\
\text { females }\end{array}$ & NA & 49 & Nuclear & $\checkmark$ & $\checkmark$ \\
\hline Sotillo & 2006 & Various & TMA & NR & NR & NA & 351 & Nuclear & $\checkmark$ & $\mathrm{X}$ \\
\hline Suraokar & 2014 & Mesothelioma & TMA & NR & NR & NA & 80 & $\begin{array}{l}\text { Nuclear \& } \\
\text { cytoplasmic }\end{array}$ & $\checkmark$ & $\checkmark$ \\
\hline
\end{tabular}




\begin{tabular}{|c|c|c|c|c|c|c|c|c|c|c|}
\hline Teixeira & 2015 & Oral cancer & NR & $\begin{array}{l}25 \text { aged }<62, \\
29 \text { aged } \geq 62\end{array}$ & $\begin{array}{l}\text { Males \& } \\
\text { females }\end{array}$ & NA & 54 & $\begin{array}{l}\text { Nuclear \& } \\
\text { cytoplasmic }\end{array}$ & $\checkmark$ & $\checkmark$ \\
\hline Thoma & 2009 & Renal & TMA & NR & NR & NA & $>200$ & Nuclear & $\checkmark$ & $\mathrm{X}$ \\
\hline Uemura & 2009 & Esophageal & TMA & $\begin{array}{l}32 \text { aged }<60 \\
28 \text { aged } \geq 60\end{array}$ & $\begin{array}{l}\text { Males \& } \\
\text { females }\end{array}$ & 60 & 60 & $\begin{array}{l}\text { Nuclear \& } \\
\text { cytoplasmic }\end{array}$ & $\checkmark$ & $\mathrm{X}$ \\
\hline Wang & 2009 & Gastric & TMA & NR & $\begin{array}{l}\text { Males \& } \\
\text { females }\end{array}$ & 102 & 102 & $\begin{array}{l}\text { Nuclear \& } \\
\text { cytoplasmic }\end{array}$ & $\checkmark$ & $\checkmark$ \\
\hline $\mathrm{Yu}$ & 2010 & Osteosarcoma & NR & $12-54(25.2)$ & $\begin{array}{l}\text { Males \& } \\
\text { females }\end{array}$ & 20 & 48 & $\begin{array}{l}\text { Nuclear \& } \\
\text { cytoplasmic }\end{array}$ & $\checkmark$ & $\checkmark$ \\
\hline Zhang & 2008 & Hepatocellular & TMA & $\begin{array}{l}184<\text { median } \\
\text { age, } 216> \\
\text { median age }\end{array}$ & $\begin{array}{l}\text { Males \& } \\
\text { females }\end{array}$ & NR & 400 & Nuclear & $\mathrm{X}$ & $\checkmark$ \\
\hline Zhao & 2014 & Endometrial & NR & NR (50.8) & Females & 30 & 63 & $\begin{array}{l}\text { Nuclear \& } \\
\text { cytoplasmic }\end{array}$ & $\checkmark$ & $\mathrm{X}$ \\
\hline
\end{tabular}

$\mathrm{NA}=$ not applicable, $\mathrm{NR}=$ not reported, $\mathrm{TMA}=$ tissue microarray, $\mathrm{UC}=$ Ulcerative Colitis.

levels. Low MAD2 levels correlated with poorer survival as evident in Figure 2. In mucinous ovarian cancers, a different outcome was obtained where low MAD2 levels correlate with decreased risk of all-cause death. However, the association between MAD2 levels and survival in mucinous cancers may not be valid as the HR is extremely close to $1(\mathrm{HR}=1.11,95 \% \mathrm{CI} ; 0.25-4.90)$ arising from a single study.

\section{Association with progression-free survival}

The meta-analyses of progression-free survival included studies published between 2010 and 2014 with five studies from East Asia and two studies from Europe (Table 1). Cancer sample cohorts ranged from 27 to 358 . The mean/median follow-up times reported ranged from $2-5$ years.

The use of TMAs or full face sections for MAD2 IHC analysis was unreported in three studies. However, most other studies utilised TMAs with one study using both TMAs and full face sections. Monoclonal antibodies were reported in five studies with two studies not reporting the type used. MAD2 nuclear staining was reported in three studies, MAD2 cytoplasmic staining was reported in one study and both MAD2 nuclear and cytoplasmic staining assessed in two studies (Table 1). MAD2 IHC

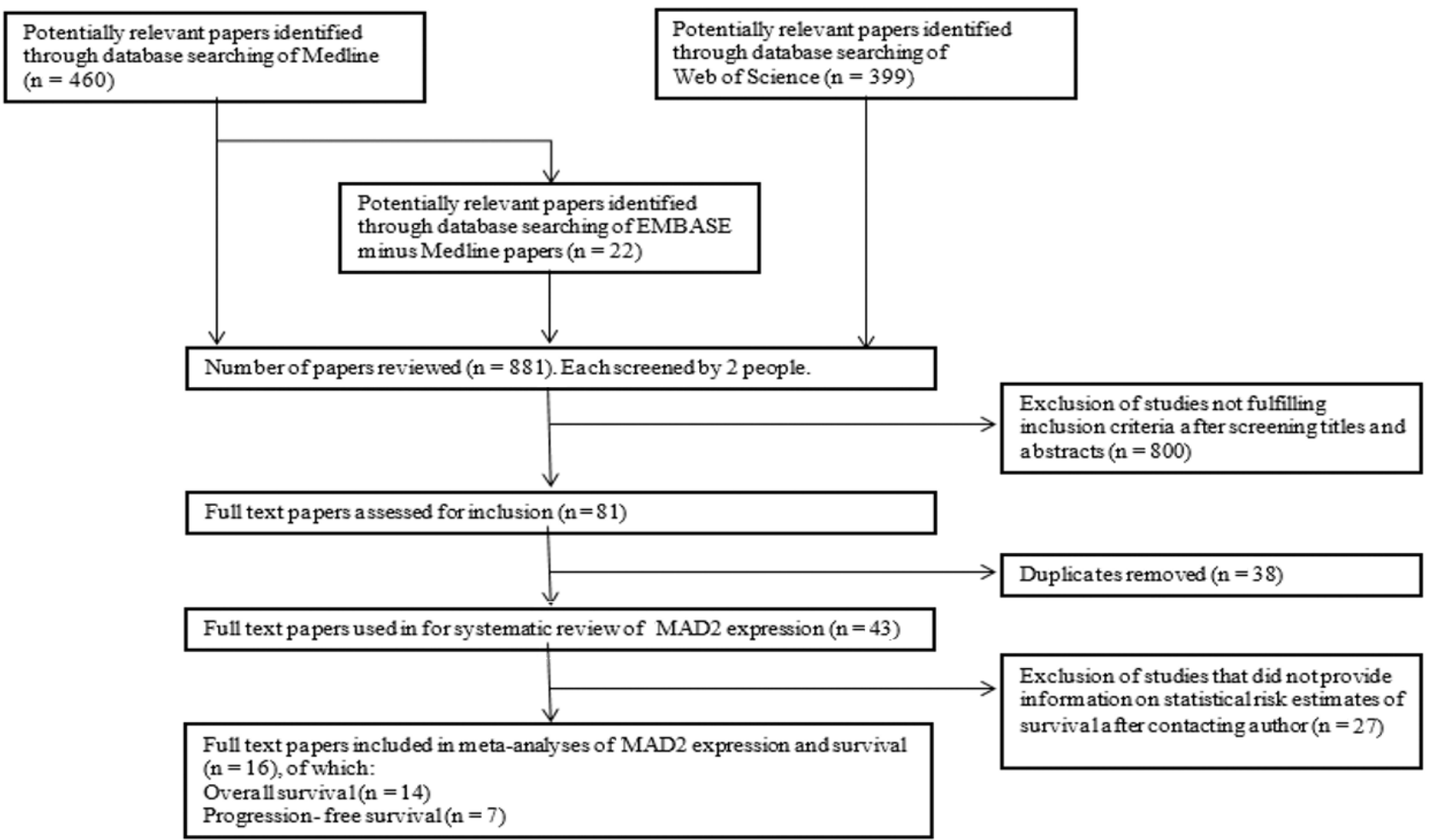

Figure 1: Flowchart of study selection that assessed MAD2 immunohistochemistry in cancer. Three databases (Medline, Embase and Web of Science) were utilised to identify potential papers for inclusion in meta-analysis. After removal of duplicates and studies not fulfilling inclusion criteria, data was extracted from these full text papers to be included in meta-analyses evaluating MAD2 percentage expression and both progression-free and overall survival in relation to MAD2 expression. 
Table 2: Descriptive characteristics and results of studies investigating MAD2 expression and cancer progression

\begin{tabular}{|c|c|c|c|c|c|c|c|}
\hline Author & Cancer site(s) & $\begin{array}{l}\text { Comparison } \\
\text { (definition)* }\end{array}$ & $\begin{array}{c}\text { Total number } \\
\text { of patients/ } \\
\text { deaths }\end{array}$ & $\begin{array}{r}\text { Mean (max.) } \\
\text { follow-up, yrs }\end{array}$ & $\begin{array}{c}\text { Relative risk } \\
(95 \% \text { CI) } \\
\text { Overall/cancer- } \\
\text { specific survival }\end{array}$ & $\begin{array}{c}\text { Relative risk } \\
(95 \% \mathrm{CI}) \\
\text { Recurrence/ } \\
\text { disease free } \\
\text { survival }\end{array}$ & Adjustments \\
\hline $\begin{array}{l}\text { Burum- } \\
\text { Auensen }\end{array}$ & Colorectal & $\begin{array}{l}\text { High v. low }(\geq \mathrm{v} .< \\
\text { median \%) }\end{array}$ & $55 / \mathrm{NR}$ & NR & $\begin{array}{l}\text { HR } 0.83,95 \% \text { CI } \\
0.41-1.66 \\
P=0.59\end{array}$ & & $\begin{array}{l}\text { Multivariate- } \\
\text { variables NR }\end{array}$ \\
\hline Choi & Bladder & $\begin{array}{l}\text { High v. low ( }>3 \% \text { v. } \\
\leq 3 \% \text {, determined by } \\
\text { receiver operating } \\
\text { characteristic curves) }\end{array}$ & $339 / 29$ & $\begin{array}{l}\text { Mean NR, } \\
\text { median was } \\
\text { given }=3.08 \\
(15.25)\end{array}$ & $\begin{array}{l}\text { HR } 2.68,95 \% \\
\text { CI } 1.29-5.55, \\
P=0.008\end{array}$ & & Unadjusted \\
\hline Furlong & Ovarian & $\begin{array}{l}\text { High v. low (intensity } \\
3-4 \text { v. 1-2) }\end{array}$ & $82 / \mathrm{NR}$ & NR & $\begin{array}{l}\text { HR } 0.54,95 \% \\
\text { CI } 0.30-0.98, \\
P=0.041\end{array}$ & $\begin{array}{l}\text { HR } 0.43,95 \% \\
\text { CI } 0.24-0.76, \\
P=0.004\end{array}$ & $\begin{array}{l}\text { Stage and } \\
\text { grade }\end{array}$ \\
\hline Genga & $\begin{array}{l}\text { Myelodysplastic } \\
\text { syndrome }\end{array}$ & $\begin{array}{l}\text { High v. low ( } \geq 50 \% \mathrm{v} \text {. } \\
\text { zero/ }<50 \%)\end{array}$ & $40 / 10$ & $\begin{array}{l}3.24 \pm 1.7 \\
(5.75)\end{array}$ & $\begin{array}{l}\text { HR } 15.79,95 \% \\
\text { CI } 2.42-102.86, \\
P=0.004\end{array}$ & & $\begin{array}{l}\text { Age, gender, } \\
\text { International } \\
\text { Prognostic } \\
\text { Scoring } \\
\text { System at } \\
\text { diagnosis }\end{array}$ \\
\hline \multirow[t]{2}{*}{ Gladhaug } & Pancreatobiliary & $\begin{array}{l}\text { High v. low (positive } \\
\text { v. negative) }\end{array}$ & $145 / 124$ & $\begin{array}{l}\text { Mean NR, } \\
\text { median was } \\
\text { given }=1.6(5)\end{array}$ & & & Unadjusted \\
\hline & Pancreas - Intestinal & $\begin{array}{l}\text { High v. low (positive } \\
\text { v. negative) }\end{array}$ & $73 / 35$ & $\begin{array}{l}\text { Mean NR, } \\
\text { median was } \\
\text { given }=1.6(5)\end{array}$ & $\begin{array}{l}\text { HR 1.11, 95\% CI } \\
0.51-2.43, P= \\
0.786\end{array}$ & & Unadjusted \\
\hline Kato & Lung & High $\mathrm{v}$ low $(\geq 4 \mathrm{v} . \leq 3)$ & $358 / \mathrm{NR}$ & $\begin{array}{l}\text { Mean NR, } \\
\text { median given = } \\
5.04(13.82)\end{array}$ & $\begin{array}{l}\text { HR } 1.78,95 \% \\
\text { CI } 1.17-2.71, \\
P=0.008\end{array}$ & $\begin{array}{l}\text { HR } 1.78,95 \% \\
\text { CI } 1.17-2.71 \\
P=0.008\end{array}$ & $\begin{array}{l}\text { Age, sex, pT } \\
\text { status, pN } \\
\text { status, pleural } \\
\text { invasion, } \\
\text { histological } \\
\text { type, smoking } \\
\text { history }\end{array}$ \\
\hline Kim & Uterine cervical & $\begin{array}{l}\text { High v. low }(\geq 25 \% \mathrm{v} . \\
<25 \%)\end{array}$ & $232 / \mathrm{NR}$ & $\begin{array}{l}\text { Mean NR, } \\
\text { median was } \\
\text { given }=2.75 \\
(10.25)\end{array}$ & & $\begin{array}{l}\text { HR } 0.83,95 \% \\
\text { CI } 0.31-2.23 \\
P=0.711\end{array}$ & Unadjusted \\
\hline Ko & Salivary duct & $\begin{array}{l}\text { High v. low (intensity } \\
3-4 \text { v. } 1-2 \text { ) }\end{array}$ & $27 / 14$ & $3.11(9.75)$ & $\begin{array}{l}\text { HR } 0.76,95 \% \\
\text { CI } 0.28-2.08 \\
P=0.59\end{array}$ & $\begin{array}{l}\text { HR } 0.84,95 \% \\
\text { CI } 0.28-2.51, \\
P=0.75\end{array}$ & Unadjusted \\
\hline $\mathrm{Li}$ & Endometrial & $\begin{array}{l}\text { High v. low (positive } \\
\text { v. negative) }\end{array}$ & $63 / 7$ & $3(5.75)$ & $\begin{array}{l}\text { OR } 17.4,95 \% \\
\text { CI } 3.5-87.62, \\
P=0.041\end{array}$ & & Unadjusted \\
\hline McGrogan & Ovarian & $\begin{array}{l}\text { High vs. low (intensity } \\
3-4 \text { v. } 1-2 \text { ) }\end{array}$ & $71 / 44$ & NR & & $\begin{array}{l}\text { HR } 0.51,95 \% \\
\text { CI } 0.23-1.10 \\
P=0.09\end{array}$ & $\begin{array}{l}\text { Tumour } \\
\text { stage, grade, } \\
\text { and optimal } \\
\text { debulking }\end{array}$ \\
\hline Nakano & Ovarian serous & $\begin{array}{l}\text { High v. low (mean } \\
\text { weighted scores 8-12 } \\
\text { v. 0-6) }\end{array}$ & $41 / 20$ & NR & $\begin{array}{l}\text { HR } 0.23,95 \% \\
\text { CI } 0.07-0.78 \\
P=0.019\end{array}$ & $\begin{array}{l}\text { HR } 0.40,95 \% \\
\text { CI } 0.15-1.08, \\
P=0.069\end{array}$ & Unadjusted \\
\hline Nakano & Ovarian mucinous & $\begin{array}{l}\text { High v. low (mean } \\
\text { weighted scores } 8-12 \\
\text { v. } 2-6 \text { ) }\end{array}$ & $128 / \mathrm{NR}$ & NR & $\begin{array}{l}\text { HR } 1.10,95 \% \\
\text { CI } 0.25-4.90, \\
P=0.903\end{array}$ & & Unadjusted \\
\hline Park & Ovarian & $\begin{array}{l}\text { High v. low (score } \geq 2 \\
\text { v. } \leq 1 \text { ) }\end{array}$ & $85 / \mathrm{NR}$ & $2(6.58)$ & & $\begin{array}{l}\text { HR } 0.26,95 \% \\
\text { CI } 0.06-1.09, \\
P=0.07\end{array}$ & $\begin{array}{l}\text { Age, stage, } \\
\text { ovarian cancer } \\
\text { type, p53 } \\
\text { expression }\end{array}$ \\
\hline
\end{tabular}




\begin{tabular}{|l|l|l|l|l|l|l|}
\hline Suraokar & Mesothelioma & $\begin{array}{l}\text { High v. low (median, } \\
\geq \text { v. }<44)\end{array}$ & $77 / 75$ & NR & $\begin{array}{l}\text { HR } 1.60,95 \% \\
\text { CI } 1.02-2.51, \\
P=0.09\end{array}$ & Unadjusted \\
\hline Yu & Osteosarcoma & $\begin{array}{l}\text { High v. low (strong v. } \\
\text { weak) }\end{array}$ & $48 / \mathrm{NR}$ & NR (9) & $\begin{array}{l}\text { HR } 4.79,95 \% \\
\text { CI } 1.45-15.80, \\
P<0.01\end{array}$ & \\
\hline Zhang & Hepatocellular & $\begin{array}{l}\text { High v. low }(\geq 10 \mathrm{v} . \\
<10 \%)\end{array}$ & $400 / 302$ & $3.29(7)$ & $\begin{array}{l}\text { HR } 1.44,95 \% \\
\text { CI } 1.16-1.80, \\
P<0.001\end{array}$ & Unadjusted \\
\hline
\end{tabular}

$\mathrm{CI}=$ Confidence intervals, $\mathrm{HR}=$ Hazard ratio, $\mathrm{NR}=$ not reported, OR: Odds ratio

staining analysis was assessed by a pathologist in two studies, while five studies did not state if a pathologist assisted in the scoring. MAD2 IHC staining was determined by at least two assessors in four studies and three studies did not state the number of assessors.

The meta-analysis of the association between MAD2 expression and progression-free survival was assessed from seven studies containing 997 patient samples (Table 2). The results from all studies indicated that lower MAD2 expression was not significantly associated with an increased risk of cancer recurrence (pooled HR $=0.65$, 95\% CI, $0.36-1.19 ; P=0.16$, Figure 3). Similar to the association with overall survival, MAD2 expression is different in ovarian cancer compared to other cancers. A pooled HR for progression-free survival in patients with high-expressing non-ovarian MAD2 tumours compared to those with low expressing MAD2 tumours was 1.29 (95\% CI, 0.74-2.25; $P=0.38$ ). Mild heterogeneity was observed $\left(I^{2}\right.$ value $\left.=36 \%, P=0.21\right)$. In contrast, a significant pooled HR of 0.43 (95\% CI, $0.29-0.65$; $P<$ 0.001 ) was evident for progression-free survival in patients with high expressing MAD2 ovarian tumours compared to those with low expressing MAD2 tumours. An $\mathrm{I}^{2}$ value of $0 \%$ was seen thereby identifying the results as consistent $(P=0.85)$. Moreover, the funnel plots for these analyses had minimal asymmetry, indicating no publication bias $(P=0.09$, Supplementary Figure 1).

\section{DISCUSSION}

The aim of this novel systematic review with metaanalyses was to summarise the extent of MAD2 expression in various tissues, and to investigate the association between MAD2 IHC expression and both overall and progression-free survival in a diverse range of cancers. The results highlight that higher MAD2 expression is

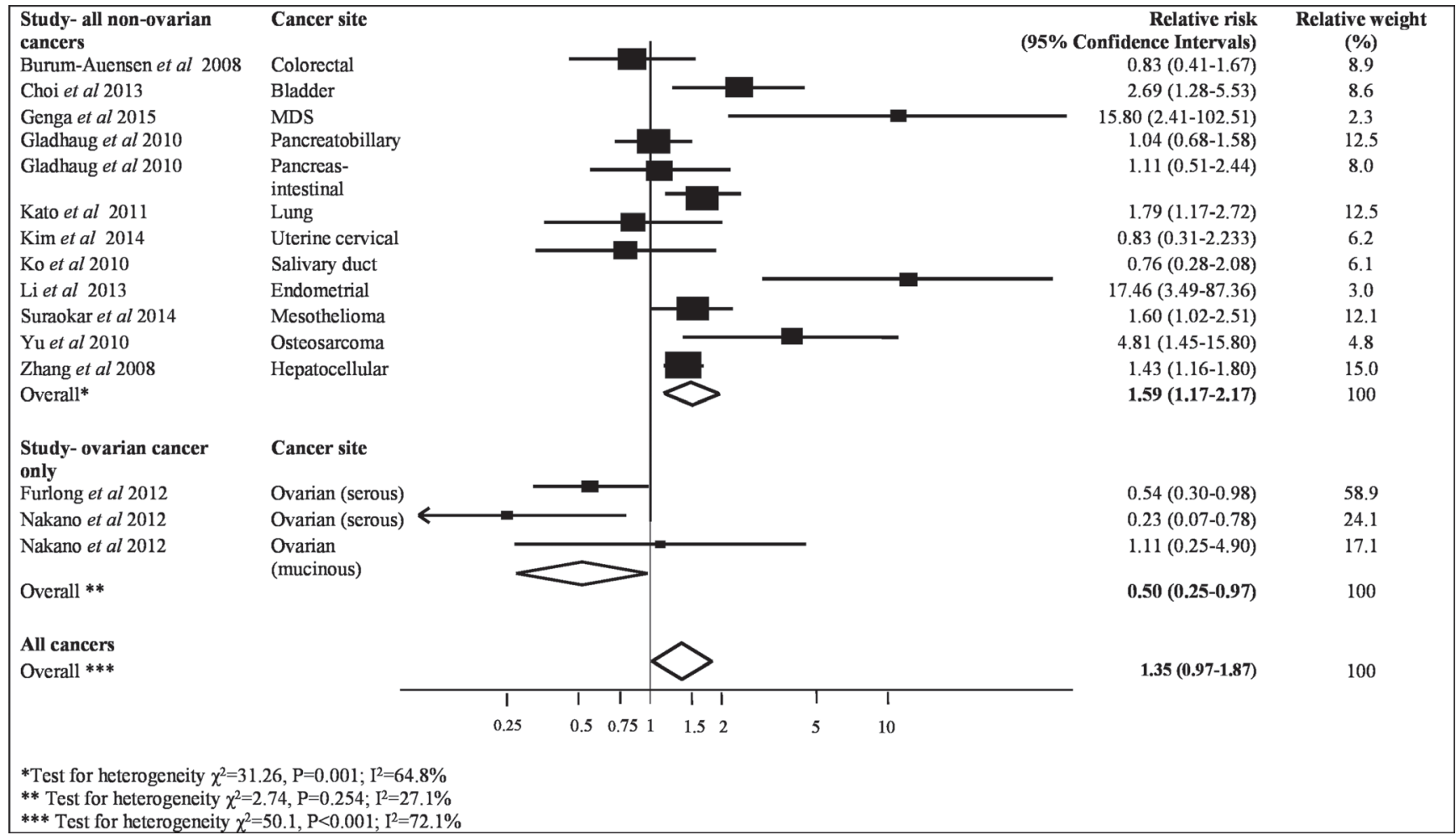

Figure 2: Meta-analysis of highest v. lowest category of MAD2 protein levels and risk to overall cancer survival. 
associated with poorer survival in cancer patients, with the exception of ovarian cancer, where conversely, higher MAD2 expression is associated with improved survival.

Our results indicated that MAD2 dysregulation is heavily tissue dependent in cancerous tissue with MAD2 IHC levels ranging from $11.1 \%$ to $100 \%$ in cancerous tissue. Dysregulation of MAD2 levels by either up- or down-regulation of the gene can result in similar genomic aberrations and contribute to poorer patient survival $[14,40]$. From our results, it is evident that high MAD2 levels are associated with increased risk of all-cause death and cancer recurrence in non-ovarian cancers while low MAD2 levels are associate with poorer patient survival in ovarian cancer. Through in vitro and in vivo studies, high MAD2 levels are known to correlate with increased cellular proliferation, cellular transformation, migration, invasiveness and cancer metastasis which could contribute to this poorer patient outcome [41-44]. In addition, a number of studies have shown that low MAD2 levels correlate with resistance to commonly utilised anticancer agents such as taxol, DNA-damaging agents, vincristine and $\gamma$-irradiation. Therefore, it is not surprising that both low or high MAD2 levels can lead to a worsen patient prognosis [20, 45-48]. We previously reported that low MAD2 levels correlated with shorter progression-free survival in high grade serous ovarian cancer patients treated with platinum alone or in combination with paclitaxel and concluded this occurred as a result of increased resistance to paclitaxel [20].

In ovarian cancer, the association of high MAD2 expression and survival is in contrast to the reported association of low MAD2 expression in the other cancer types included in this study and raises many questions about why MAD2 levels in ovarian cancer produce such a different response to patient survival. Currently, there is no explanation for this outcome. However, one possible explanation could be linked to the fact that unlike most cancer types that metastasise mainly via haematogenous or lymphatic routes, ovarian cancer, especially the most common and lethal type high grade serous carcinoma, metastasises through peritoneal dissemination [49]. Therefore as ovarian cancers progress and metastasise, they may possibly become less reliant on MAD2 expression as previously reported in osteosarcoma [33]. Another possibility for the dysregulation of MAD2 expression could be related to the regulation of MAD2 by BRCA1 [11]. BRCA1, which is mutated in $10 \%$ of ovarian cancers, is a transcriptional regulator of MAD2 and the aberrant activity of mutant BRCA1 in ovarian cancer may lead to altered transcriptional regulation of MAD2 expression $[11,50]$. Furthermore, ovarian tumours with high MAD2 levels were previously shown to be associated with increased sensitivity to taxol and improved patient survival, which may indicate that taxol response in ovarian tumours is possibly more dependent on the SAC activity of MAD2 than other cancer types [20,51].

From the meta-analysis, the different subtypes of ovarian cancer have distinctive survival responses in terms of MAD2 expression. Studies of high grade serous ovarian cancer have shown that low MAD2 levels lead to poorer patient survival. In contrast, mucinous ovarian cancer appears to have a weaker inverse association between MAD2 levels and survival. A possible reasoning for this is that p53 and BRCA1, known regulators of MAD2, are commonly mutated in high serous ovarian cancer ( $T p 53$ mutation is ubiquitous in ovarian high grade serous carcinoma) and mutations in these genes are uncommon in other ovarian cancer subtypes such as mucinous, clear cell, endometrioid and low grade serous [11, 52]. Similarly in breast cancer, where p53 and BRCA1 are also regularly mutated, high MAD2 levels are associated with improved breast cancer specific survival [53]. Additionally, high

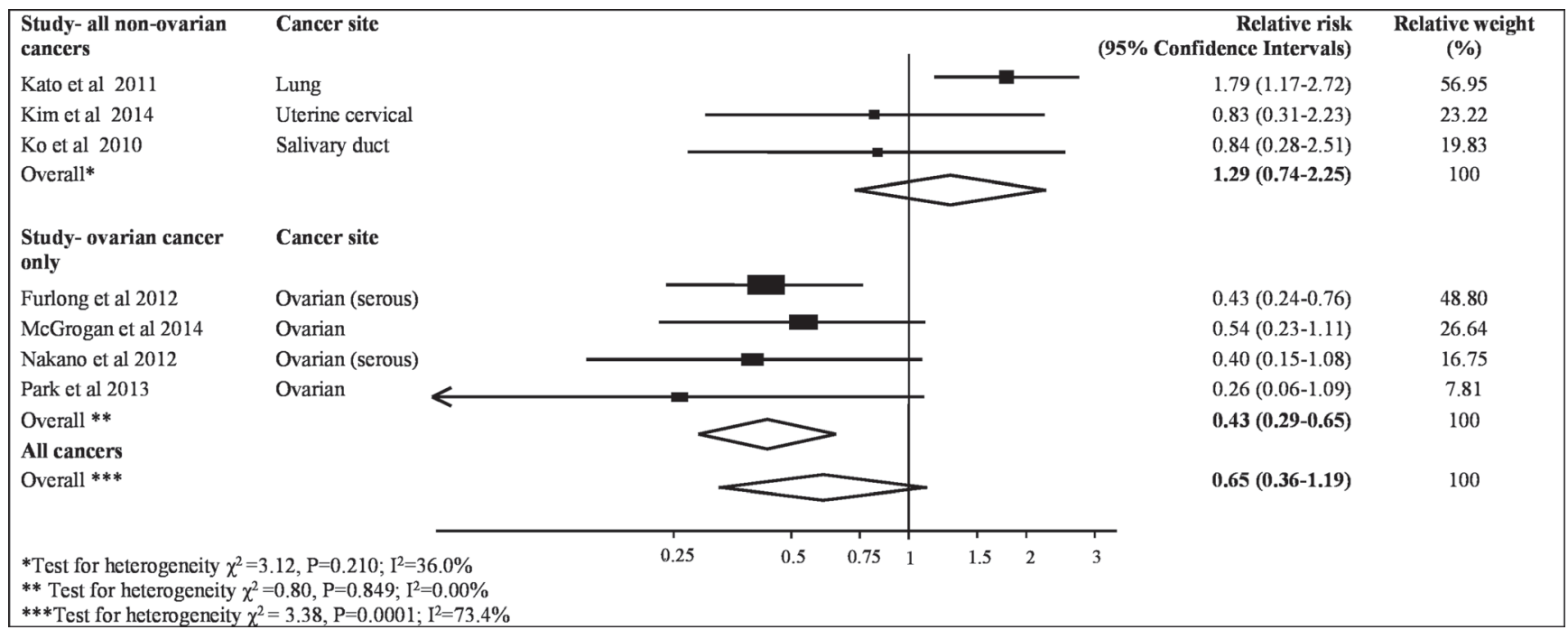

Figure 3: Meta-analysis of highest $\mathrm{v}$. lowest category of MAD2 protein levels and risk to progression free cancer survival. 
grade serous ovarian cancers express lower levels of E-cadherin and higher levels of $\mathrm{N}$-cadherin compared to mucinous which is suggestive of a more epithelialmesenchymal transition phenotype which in-turn triggers tumour metastasis and possibly reduce the requirement of MAD2 for tumour spread [54, 55]. However, due to the limited number of studies on MAD2 expression in ovarian cancer, we cannot conclude if different ovarian subtypes have different survival rates depending on MAD2 expression. Further analysis of MAD2 IHC expression in ovarian cancer may result in an IHC biomarker capable of stratifying the various ovarian cancers subtypes.

The heterogeneity in the meta-analysis of the correlation of MAD2 expression and overall survival in non-ovarian cancer studies was considerable between studies $(64.8 \%)$. This could be attributable to the methodological diversity between studies, including sub-cellular location evaluated, scoring method utilised, expression threshold chosen and cancer site investigated. However, heterogeneity associated with meta-analyses of MAD2 expression and ovarian cancer prognosis was low.

The primary strength of this review lies in its ability to determine the effect of MAD2 expression on cancer survival for the first time, taken from a robust search of three databases for relevant studies. We were also able to standardise comparator groups, displaying all results as high v. low MAD2 levels, which overcomes potential confusion when comparing results from studies reporting high $\mathrm{v}$. low or low $\mathrm{v}$. high comparisons of MAD2 expression in relation to progression. The utility of prognostic markers are relevant to both understanding the mechanisms of progression and the ability to predict patient outcome (who may benefit from more/less intensive treatments or follow-up regimens). MAD2 could also be combined with other cell cycle proteins such as P27, CDC20, BUBR1. However, there is limited evidence to suggest it would improve the prognostic ability of MAD2 $[21,32,41,56,57]$. Furthermore, there was no evidence of publication bias associated with the meta-analyses reported in this study which increases the robustness of the results.

One of the limitations of this review is that currently there is no standardised method for MAD2 IHC evaluation. Standardisation is vital across the entire IHC process from pre- to post-analytical stages and across laboratories to allow comparison between studies [58, 59]. This was particularly noticeable in the evaluation scoring system, where in some cases only MAD2 expression positivity was determined with the degree or percentage of MAD2 staining intensity not considered. Furthermore, the arbitrary cut-off chosen to indicate high MAD2 expression differs from study to study. Between-study variances may also have resulted from diverse populations utilised in these studies especially since a number of the studies were quite small. Standardisation of these factors across studies will allow more comparable studies and provide more robust results. Another limitation is that a meta- analysis for cancer-specific survival according to MAD2 expression was unable to be undertaken due to a lack of studies reporting on this outcome. Also the majority of the studies utilised in this review were unadjusted for confounders known to affect survival of cancer patients such as age and stage [60,61]. It is therefore difficult to determine how age and stage would affect the association of MAD2 expression on patient survival [62-64]. Of note, in the study that adjusted for age and stage the authors demonstrated that the association of MAD2 expression and survival was independent of these two confounders [25]. Therefore, future studies to analyse MAD2 IHC expression and survival should adjust for known cofounders to improve the reliability of results. Furthermore, as the studies examining MAD2 expression by IHC have utilised different sample numbers, power analysis should be considered before the study is undertaken to ensure that the data correctly identifies a statistical significant difference $[65,66]$. Tissue microarrays may make a greater number of samples more achievable [67]. Despite these limitations, the overall outcomes remained consistent.

Recommendations for future studies evaluating the association of MAD2 IHC expression include standardising the reporting of results investigating high vs. low MAD2 expression (the cut-offs may differ between different tumour types), and include required statistical values in order to undertake a meta-analysis such as HR and $95 \%$ CI. Additional studies should adjust for known clinical prognostic factors such as age and stage and also carry out power analysis. In this review, apart from ovarian cancer, there has only been one study in each cancer type that has met the required statistical findings in order to be included in a meta-analysis (Table 2). Thus, more studies in each cancer type are required to definitively determine if the correlation of MAD2 IHC expression with patient survival is cancer-specific. Furthermore, investigation of the molecular pathways involving MAD2 is essential to help researchers understand the mechanism behind the results of this review. Recent studies have also highlighted a potential therapeutic role for MAD2 where silencing of the MAD2 gene using siRNA lead to increased apoptotic cell death in a non-small cell lung cancer model [68]. Additionally, MAD2's role as a predictive biomarker could also be particularly important. Further studies of cancer samples from patients treated with and without taxol/DNAdamaging agents would evaluate if MAD2 expression could predict the efficacy of these treatments on patient survival.

In conclusion, this review illustrates the potential for MAD2 IHC as a prognostic biomarker in cancer, especially in ovarian cancer where there is approximately a $50 \%$ lower risk of death or tumour recurrence in patients in the higher MAD2 expression category compared to the lower. An opposing prognostic role for increased risk of death in other cancer sites displaying high MAD2 expression may exist. Further studies are critical to assess the clinical utility of a MAD2 IHC biomarker and the 
molecular pathways affected by MAD2 that may improve patient outcomes. We outline recommendations for the standardised conduct and reporting of MAD2 expression studies in relation to cancer progression outcomes.

\section{MATERIALS AND METHODS}

This systematic review and meta-analysis adhered to the guidelines provided by the Preferred Reporting Items for Systematic Reviews and Meta-Analyses (PRISMA) statement [22].

\section{Search strategy}

Systematic literature searches were performed using three electronic databases; Medline (US National Library of Medicine, National Institutes of Health, Bethesda, Maryland, USA), Embase (Reed Elsevier PLC, Amsterdam, The Netherlands) and Web of Science (Thomson Reuters, New York, USA) from their origin until week five October 2015. A systematic search to identify publications, in any language, was applied using the following keywords and/or Medical Subject Heading (MeSH) terms; (Mitotic Arrest Deficient-Like 1 OR MAD2 or HSMAD2 or MAD2-Like Protein 1 OR Mitotic Arrest Deficient 2-Like Protein 1 OR Mitotic Spindle Assembly Checkpoint Protein MAD2A) AND (carcinoma(s) OR cancer(s) OR neoplasm(s) OR tumo (u) r(s) OR adenocarcinoma(s)).

\section{Study selection}

Inclusion criteria for studies were defined using the PICO model (population, intervention, control/comparison and outcome). The population included patients with any type of cancer. In order to be included in this systematic review, these studies needed to include the intervention which was an IHC method for the assessment of MAD2 expression. Studies must also have reported a comparison between high/positive and low/negative MAD2 levels in cancerous tissue. The outcome of the study must have reported either the proportion of tissue samples exhibiting MAD2 expression (or data from which this proportion could be calculated) and/or the statistical association between MAD2 and prognosis in cancer patients. Conference abstracts and poster presentations were excluded. Only human studies and literature available in the English language were included. Where publications reported on a sample source that was entirely overlapping and reported on the same outcomes, only the largest/most recent set of results was retained.

The principal reviewer (T. Byrne) screened all titles and abstracts, and two other reviewers (F. Furlong and J. Cooper) independently screened half of the titles and abstracts each. In cases where an abstract was unavailable or the article's significance was unclear, the full article was acquired for further examination. Those identified by any of the two reviewers for possible inclusion were brought forward for full text review.

\section{Data extraction}

From the full text of identified articles, where available, the following data was extracted by the principal reviewer (T.Byrne): authors, year of publication, journal name, location and number of centres samples were obtained from, primary aim of the study, source and method which samples were obtained, number of participants, mean age and sex of participants, immunohistochemical methods, type of antibody, manufacturer and dilution of antibody, type of staining, scoring system, IHC assessment procedure, number of patients with positive/negative/ weak/moderate/strong MAD2 expression tumours, followup time, survival, and/or recurrence results including reported hazard ratios (HRs), confidence intervals (CIs) and associated $p$-values. Authors from publications that did not have all required information were contacted to obtain information and summary-level data was utilised for meta-analysis.

\section{Statistical analysis}

Meta-analyses were conducted to determine the association between MAD2 expression and overall survival and progression-free survival, where possible. Several of these studies did not present the results required for meta-analysis as high v. low comparisons of MAD2 expression. In the first instance authors were contacted to request information (provided by Furlong et al, Genga et al, Ko et al) $[20,23,24]$. For one study, Park et al, the HR for low v. high comparison was inverted in order to achieve comparability with studies where the HR for high v. low comparison was provided [25]. For other studies, the HR and 95\% CI were derived by applying Parmar's methods [26] when the number of observed deaths in the high and low comparison groups had been presented together with the log-rank $p$-value for the associated Kaplan Meier curve (conducted for Li et al, Zhang et al, Nakano et al - serous and mucinous ovarian cancer studies, Suraokar et al, Kim, Choi, Yu, Gladhaug et al and Genga et al studies) [21, 23, 27-34]. Adjusted/unadjusted HRs and 95\% CI (with the maximally adjusted rates used where possible) were combined and weighted to provide pooled estimates. A random effects model was utilised in order to account for the anticipated heterogeneity between studies. Subgroup analysis was possible by cancer type for ovarian cancer studies, where at least three studies had been published, but not for other cancer types. The extent of heterogeneity in the pooled estimates was calculated using the $\chi 2$ test and $\mathrm{I}^{2}$ statistic. The $\mathrm{I}^{2}$ statistic estimates the degree of variation between findings that is a result of heterogeneity rather than chance [35]. An I ${ }^{2}$ statistic above 
$25 \%, 50 \%$ or $75 \%$ was decided to denote mild, moderate and high heterogeneity respectively [36]. In order to evaluate publication bias, funnel plots were constructed according to the Begg and Egger methods, by plotting relative risks to their corresponding standard errors $[37,38]$. In addition, sensitivity analysis was conducted to determine excessive influences of studies by removing each study individually and assessing the effect on pooled estimates and the heterogeneity $\mathrm{I}^{2}$ statistic [39]. Statistical analysis was conducted utilising Stata version 11.2 software (Stata Corporation, College Station, TX, USA).

\section{Abbreviations}

MAD2 mitotic arrest deficiency protein 2; SAC spindle assembly checkpoint; BRCA1 breast cancer 1; CHFR Checkpoint with Forkhead And Ring Finger Domains, E3 Ubiquitin Protein Ligase; CIs confidence intervals; E2F E2 factor; HRs hazard ratios; IHC immunohistochemistry; MeSH Medical Subject Heading; PRISMA Preferred Reporting Items for Systematic Reviews and Meta-Analyses; TMAs tissue microarrays.

\section{Authors' contributions}

TB, HC, JC, GMCC, AMcC and FF coneived the project and contributed to study design; TB, JC, FF performed data collection; TB, HC, JC and FF analysed and interpreted the data with $\mathrm{HC}$ undertaking the statistical analysis; TB wrote the manuscript with input from all authors; all authors read and approved the final version of the manuscript.

\section{CONFLICTS OF INTEREST}

No conflicts of interest exist for any author.

\section{FUNDING}

The project was funded by Department of Employment and Learning, Northern Ireland. No disclaimers.

\section{REFERENCES}

1. Mossaid I, Fahrenkrog B. Complex Commingling: Nucleoporins and the Spindle Assembly Checkpoint. Cells. 2015; 4:706-25.

2. Sotillo R, Hernando E, Díaz-Rodríguez E, TeruyaFeldstein J, Cordón-Cardo C, Lowe SW, Benezra R. Mad2 overexpression promotes aneuploidy and tumorigenesis in mice. Cancer Cell. 2007; 11:9-23.

3. Schvartzman JM, Duijf PH, Sotillo R, Coker C, Benezra R. Mad2 is a critical mediator of the chromosome instability observed upon $\mathrm{Rb}$ and p53 pathway inhibition. Cancer Cell. 2011; 19:701-14.
4. Kabeche L, Compton DA. Checkpoint-independent stabilization of kinetochore-microtubule attachments by Mad2 in human cells. Curr Biol. 2012; 22:638-44.

5. Sotillo R, Schvartzman JM, Socci ND, Benezra R. Mad2induced chromosome instability leads to lung tumour relapse after oncogene withdrawal. Nature. 2010; 464:436-40.

6. Michel L, Benezra R, Diaz-Rodriguez E. MAD2 dependent mitotic checkpoint defects in tumorigenesis and tumor cell death: a double edged sword. Cell Cycle. 2004; 3:990-92.

7. O’Neill TJ, Zhu Y, Gustafson TA. Interaction of MAD2 with the carboxyl terminus of the insulin receptor but not with the IGFIR. Evidence for release from the insulin receptor after activation. J Biol Chem. 1997; 272:10035-40.

8. Poelzl G, Kasai Y, Mochizuki N, Shaul PW, Brown M, Mendelsohn ME. Specific association of estrogen receptor beta with the cell cycle spindle assembly checkpoint protein, MAD2. Proc Natl Acad Sci USA. 2000; 97:2836-39.

9. Nelson KK, Schlöndorff J, Blobel CP. Evidence for an interaction of the metalloprotease-disintegrin tumour necrosis factor alpha convertase (TACE) with mitotic arrest deficient 2 (MAD2), and of the metalloprotease-disintegrin MDC9 with a novel MAD2-related protein, MAD2beta. Biochem J. 1999; 343:673-80.

10. Date DA, Burrows AC, Venere M, Jackson MW, Summers MK. Coordinated regulation of $\mathrm{p} 31$ (Comet) and $\mathrm{Mad} 2$ expression is required for cellular proliferation. CellCycle. $2013 ; 12: 3824-32$.

11. Wang RH, Yu H, Deng CX. A requirement for breast-cancerassociated gene 1 (BRCA1) in the spindle checkpoint. Proc Natl Acad Sci USA. 2004; 101:17108-13.

12. Menssen A, Epanchintsev A, Lodygin D, Rezaei N, Jung P, Verdoodt B, Diebold J, Hermeking H. c-MYC delays prometaphase by direct transactivation of MAD2 and BubR1: identification of mechanisms underlying c-MYCinduced DNA damage and chromosomal instability. Cell Cycle. 2007; 6:339-52.

13. Keller JA, Petty EM. CHFR binds to and regulates MAD2 in the spindle checkpoint through its cysteine-rich domain. Biochem Biophys Res Commun. 2011; 409:389-93.

14. Hernando E, Nahlé Z, Juan G, Diaz-Rodriguez E, Alaminos M, Hemann M, Michel L, Mittal V, Gerald W, Benezra R, Lowe SW, Cordon-Cardo C. Rb inactivation promotes genomic instability by uncoupling cell cycle progression from mitotic control. Nature. 2004; 430:797-802.

15. Furlong F, Prencipe M, McGoldrick A, McGettigan P, Carney D, Doyle E, Kay E, McCann A. miR-433 overexpression attenuates the spindle assembly checkpoint response to paclitaxel. Breast Cancer Res. 2010; 12:P35.

16. Tambe M, Pruikkonen S, Mäki-Jouppila J, Chen P, Elgaaen BV, Straume AH, Huhtinen K, Cárpen O, Lønning PE, Davidson B, Hautaniemi S, Kallio MJ. Novel Mad2targeting miR-493-3p controls mitotic fidelity and cancer 
cells' sensitivity to paclitaxel. Oncotarget. 2016; 7:1226785. https://doi.org/10.18632/oncotarget.7860.

17. Li GQ, Li H, Zhang HF. Mad2 and p53 expression profiles in colorectal cancer and its clinical significance. World J Gastroenterol. 2003; 9:1972-75.

18. Pati D, Haddad BR, Haegele A, Thompson H, Kittrell FS, Shepard A, Montagna C, Zhang N, Ge G, Otta SK, McCarthy M, Ullrich RL, Medina D. Hormone-induced chromosomal instability in p53-null mammary epithelium. Cancer Res. 2004; 64:5608-16.

19. Wang L, Yin F, Du Y, Du W, Chen B, Zhang Y, Wu K, Ding J, Liu J, Fan D. MAD2 as a key component of mitotic checkpoint: A probable prognostic factor for gastric cancer. Am J Clin Pathol. 2009; 131:793-801.

20. Furlong F, Fitzpatrick P, O'Toole S, Phelan S, McGrogan B, Maguire A, O’Grady A, Gallagher M, Prencipe M, McGoldrick A, McGettigan P, Brennan D, Sheils O, et al. Low MAD2 expression levels associate with reduced progression-free survival in patients with high-grade serous epithelial ovarian cancer. J Pathol. 2012; 226:746-55.

21. Choi JW, Kim Y, Lee JH, Kim YS. High expression of spindle assembly checkpoint proteins CDC20 and MAD2 is associated with poor prognosis in urothelial bladder cancer. Virchows Arch. 2013; 463:681-87.

22. Pérez de Castro I, de Cárcer G, Malumbres M. A census of mitotic cancer genes: new insights into tumor cell biology and cancer therapy. Carcinogenesis. 2007; 28:899-912.

23. Teixeira JH, Silva P, Faria J, Ferreira I, Duarte P, Delgado ML, Queirós O, Moreira R, Barbosa J, Lopes CA, do Amaral JB, Monteiro LS, Bousbaa H. Clinicopathologic significance of BubR1 and Mad2 overexpression in oral cancer. Oral Dis. 2015; 21:713-20.

24. Bargiela-Iparraguirre J, Prado-Marchal L, Pajuelo-Lozano N, Jiménez B, Perona R, Sánchez-Pérez I. Mad2 and BubR1 modulates tumourigenesis and paclitaxel response in MKN45 gastric cancer cells. Cell Cycle. 2014; 13:3590-601.

25. Tanaka K, Nishioka J, Kato K, Nakamura A, Mouri T, Miki C, Kusunoki M, Nobori T. Mitotic checkpoint protein hsMAD2 as a marker predicting liver metastasis of human gastric cancers. Jpn J Cancer Res. 2001; 92:952-58.

26. Yu L, Liu S, Guo W, Zhang B, Liang Y, Feng Q. Upregulation of Mad2 facilitates in vivo and in vitro osteosarcoma progression. Oncol Rep. 2012; 28:2170-76.

27. Sudo T, Nitta M, Saya H, Ueno NT. Dependence of paclitaxel sensitivity on a functional spindle assembly checkpoint. Cancer Res. 2004; 64:2502-08.

28. Hao X, Zhou Z, Ye S, Zhou T, Lu Y, Ma D, Wang S. Effect of $\mathrm{Mad} 2$ on paclitaxel-induced cell death in ovarian cancer cells. J Huazhong Univ Sci Technolog Med Sci. 2010; 30:620-25.

29. Cheung HW, Jin DY, Ling MT, Wong YC, Wang Q, Tsao SW, Wang X. Mitotic arrest deficient 2 expression induces chemosensitization to a DNA-damaging agent, cisplatin, in nasopharyngeal carcinoma cells. Cancer Res. 2005; 65:1450-58.
30. Fung MK, Cheung HW, Wong HL, Yuen HF, Ling MT, Chan $\mathrm{KW}$, Wong YC, Cheung AL, Wang X. MAD2 expression and its significance in mitotic checkpoint control in testicular germ cell tumour. Biochim Biophys Acta. 2007; 1773:821-32.

31. Lengyel E. Ovarian cancer development and metastasis. Am J Pathol. 2010; 177:1053-64.

32. Yu L, Guo WC, Zhao SH, Tang J, Chen JL. Mitotic arrest defective protein 2 expression abnormality and its clinicopathologic significance in human osteosarcoma. APMIS. 2010; 118:222-29.

33. Liu G, Yang D, Sun Y, Shmulevich I, Xue F, Sood AK, Zhang W. Differing clinical impact of BRCA1 and BRCA2 mutations in serous ovarian cancer. Pharmacogenomics. 2012; 13:1523-35.

34. Fung MK, Cheung HW, Ling MT, Cheung AL, Wong YC, Wang X. Role of MEK/ERK pathway in the MAD2mediated cisplatin sensitivity in testicular germ cell tumour cells. Br J Cancer. 2006; 95:475-84.

35. Mullan PB, Quinn JE, Harkin DP. The role of BRCA1 in transcriptional regulation and cell cycle control. Oncogene. 2006; 25:5854-63.

36. O'Reilly EA, Sharma S, Harrison M, Weiner-Gorzel K, Kelly C, Maguire A, McCormack J, Conlon S, Aherne S, Beggan C, Bambury R, Dorsey T, Ambs S, et al. Low nuclear MAD2 expression is associated with of lack of response to chemotherapy and radiotherapy in oestrogen receptor negative breast cancer patients. Int J Surg. 2013; 11:592.

37. Brown J, Frumovitz M. Mucinous tumors of the ovary: current thoughts on diagnosis and management. Curr Oncol Rep. 2014; 16:389.

38. Putzke AP, Ventura AP, Bailey AM, Akture C, OpokuAnsah J, Celiktaş M, Hwang MS, Darling DS, Coleman IM, Nelson PS, Nguyen HM, Corey E, Tewari M, et al. Metastatic progression of prostate cancer and e-cadherin regulation by zeb1 and SRC family kinases. Am J Pathol. 2011; 179:400-10.

39. Kim Y, Choi JW, Lee JH, Kim YS. MAD2 and CDC20 are upregulated in high-grade squamous intraepithelial lesions and squamous cell carcinomas of the uterine cervix. Int $\mathrm{J}$ Gynecol Pathol. 2014; 33:517-23.

40. Duncan TJ, Al-Attar A, Rolland P, Harper S, Spendlove I, Durrant LG. Cytoplasmic p27 expression is an independent prognostic factor in ovarian cancer. Int J Gynecol Pathol. $2010 ; 29: 8-18$.

41. Li GQ, Zhang HF. Mad2 and p27 expression profiles in colorectal cancer and its clinical significance. World $\mathrm{J}$ Gastroenterol. 2004; 10:3218-20.

42. Shi SR, Shi Y, Taylor CR. Antigen retrieval immunohistochemistry: review and future prospects in research and diagnosis over two decades. J Histochem Cytochem. 2011; 59:13-32.

43. Taylor CR. Quantitative in situ proteomics; a proposed pathway for quantification of immunohistochemistry at the light-microscopic level. Cell Tissue Res. 2015; 360:109-20. 
44. Clark TG, Bradburn MJ, Love SB, Altman DG. Survival analysis part I: basic concepts and first analyses. Br J Cancer. 2003; 89:232-38.

45. Chan JK, Loizzi V, Lin YG, Osann K, Brewster WR, DiSaia PJ. Stages III and IV invasive epithelial ovarian carcinoma in younger versus older women: what prognostic factors are important? Obstet Gynecol. 2003; 102:156-61.

46. Agarwal R, Kaye SB. Prognostic factors in ovarian cancer: how close are we to a complete picture? Ann Oncol. 2005; 16:4-6.

47. Clark TG, Stewart ME, Altman DG, Gabra H, Smyth JF. A prognostic model for ovarian cancer. Br J Cancer. 2001; 85:944-52.

48. McKay A, Donaleshen J, Helewa RM, Park J, Wirtzfeld D, Hochman D, Singh H, Turner D. Does young age influence the prognosis of colorectal cancer: a population-based analysis. World J Surg Oncol. 2014; 12:370.

49. Park PE, Jeong JY, Kim SZ, Park JY. MAD2 Expression in Ovarian Carcinoma: Different Expression Patterns and Levels among Various Types of Ovarian Carcinoma and Its Prognostic Significance in High-Grade Serous Carcinoma. Korean J Pathol. 2013; 47:418-25.

50. Kopans DB, Halpern E, Hulka CA. Statistical power in breast cancer screening trials and mortality reduction among women 40-49 years of age with particular emphasis on the National Breast Screening Study of Canada. Cancer. 1994; 74:1196-203.

51. Kraemer HC, Kupfer DJ. Size of treatment effects and their importance to clinical research and practice. Biol Psychiatry. 2006; 59:990-96.

52. Torlakovic EE, Riddell R, Banerjee D, El-Zimaity H, Pilavdzic D, Dawe P, Magliocco A, Barnes P, Berendt R, Cook D, Gilks B, Williams G, Perez-Ordonez B, et al, and Canadian Association of Pathologists-Association canadienne des pathologistes National Standards Committee. Canadian Association of Pathologists-Association canadienne des pathologistes National Standards Committee/ Immunohistochemistry: best practice recommendations for standardization of immunohistochemistry tests. Am J Clin Pathol. 2010; 133:354-65.

53. Nascimento AV, Singh A, Bousbaa H, Ferreira D, Sarmento B, Amiji MM. Mad2 checkpoint gene silencing using epidermal growth factor receptor-targeted chitosan nanoparticles in non-small cell lung cancer model. Mol Pharm. 2014; 11:3515-27.

54. Moher D, Liberati A, Tetzlaff J, Altman DG, and PRISMA Group. Preferred reporting items for systematic reviews and meta-analyses: the PRISMA statement. PLoS Med. 2009; 6:e1000097

55. Genga KR, Filho FD, Ferreira FV, de Sousa JC, Studart FS, Magalhães SM, Heredia FF, Pinheiro RF. Proteins of the mitotic checkpoint and spindle are related to chromosomal instability and unfavourable prognosis in patients with myelodysplastic syndrome. J Clin Pathol. 2015; 68:381-87.

56. Ko YH, Roh JH, Son YI, Chung MK, Jang JY, Byun H, Baek $\mathrm{CH}$, Jeong HS. Expression of mitotic checkpoint proteins BUB1B and MAD2L1 in salivary duct carcinomas. J Oral Pathol Med. 2010; 39:349-55.

57. Parmar MK, Torri V, Stewart L. Extracting summary statistics to perform meta-analyses of the published literature for survival endpoints. Stat Med. 1998; 17:2815-34.

58. Li L, Xu DB, Zhao XL, Hao TY. Combination analysis of Bub1 and Mad2 expression in endometrial cancer: act as a prognostic factor in endometrial cancer. Arch Gynecol Obstet. 2013; 288:155-65.

59. Zhang SH, Xu AM, Chen XF, Li DH, Sun MP, Wang YJ. Clinicopathologic significance of mitotic arrest defective protein 2 overexpression in hepatocellular carcinoma. Hum Pathol. 2008; 39:1827-34.

60. Nakano Y, Sumi T, Teramae M, Morishita M, Fukuda T, Terada H, Yoshida H, Matsumoto Y, Yasui T, Ishiko O. Expression of the mitotic-arrest deficiency 2 is associated with chemotherapy resistance in ovarian serous adenocarcinoma. Oncol Rep. 2012; 28:1200-04.

61. Nakano Y, Sumi T, Morishita M, Fukuda T, Nobeyama H, Yoshida H, Matsumoto Y, Yasui T, Ishiko O. Mitotic arrest deficiency 2 induces carcinogenesis in mucinous ovarian tumors. Oncol Lett. 2012; 3:281-86.

62. Suraokar MB, Nunez MI, Diao L, Chow CW, Kim D, Behrens C, Lin H, Lee S, Raso G, Moran C, Rice D, Mehran R, Lee JJ, et al. Expression profiling stratifies mesothelioma tumors and signifies deregulation of spindle checkpoint pathway and microtubule network with therapeutic implications. Ann Oncol. 2014; 25:1184-92.

63. Gladhaug IP, Westgaard A, Schjølberg AR, BurumAuensen E, Pomianowska E, Clausen OP. Spindle proteins in resected pancreatic head adenocarcinomas: BubR1 is an independent prognostic factor in pancreatobiliary-type tumours. Histopathology. 2010; 56:345-55.

64. Higgins JP, Thompson SG. Quantifying heterogeneity in a meta-analysis. Stat Med. 2002; 21:1539-58.

65. Higgins JP, Thompson SG, Deeks JJ, Altman DG. Measuring inconsistency in meta-analyses. BMJ. 2003; 327:557-60.

66. Begg CB, Mazumdar M. Operating characteristics of a rank correlation test for publication bias. Biometrics. 1994; 50:1088-101.

67. Egger M, Davey Smith G, Schneider M, Minder C. Bias in meta-analysis detected by a simple, graphical test. BMJ. 1997; 315:629-34.

68. Patsopoulos NA, Evangelou E, Ioannidis JP. Sensitivity of between-study heterogeneity in meta-analysis: proposed metrics and empirical evaluation. Int J Epidemiol. 2008; 37:1148-57. 